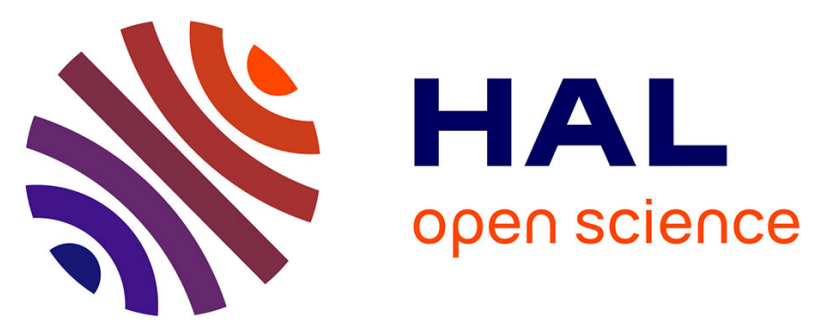

\title{
Genetic parameters and halothane genotype effect for residual feed intake in piétrain growing pigs
}

Romain Saintilan, Isabelle Mérour, Sandrine Schwob, Pierre Sellier, Jean

Pierre Bidanel, Hélène Gilbert

\section{To cite this version:}

Romain Saintilan, Isabelle Mérour, Sandrine Schwob, Pierre Sellier, Jean Pierre Bidanel, et al.. Genetic parameters and halothane genotype effect for residual feed intake in piétrain growing pigs. 9. World Congress on Genetics Applied to Livestock Production, Aug 2010, Leipzig, Germany. hal01193521

\section{HAL Id: hal-01193521 \\ https://hal.science/hal-01193521}

Submitted on 3 Jun 2020

HAL is a multi-disciplinary open access archive for the deposit and dissemination of scientific research documents, whether they are published or not. The documents may come from teaching and research institutions in France or abroad, or from public or private research centers.
L'archive ouverte pluridisciplinaire HAL, est destinée au dépôt et à la diffusion de documents scientifiques de niveau recherche, publiés ou non, émanant des établissements d'enseignement et de recherche français ou étrangers, des laboratoires publics ou privés. 


\title{
Genetic Parameters And Halothane Genotype Effect For Residual Feed Intake In Piétrain Growing Pigs
}

\author{
R. Saintilan ${ }^{\dagger}$, I. Mérour ${ }^{\ddagger}, \mathrm{S}$. Schwob ${ }^{\ddagger}$, P. Sellier ${ }^{\dagger}, \mathrm{J}$. Bidanel ${ }^{\ddagger}$, and H. Gilbert ${ }^{\dagger}$
}

\section{Introduction}

Residual feed intake (RFI) is defined as the difference between observed feed intake and that predicted on the basis of maintenance and production requirements (Koch, R. M., Swiger, L. A., Chambers, D., et al., 1963; Kennedy, B. W., Van der Werf, J. H., and Meuwissen, T.-H. E., 1993). It is an alternate way of assessing feed efficiency (FE) which is usually estimated by the ratio of feed intake to body weight gain. To our knowledge, genetic variation in RFI of growing pigs has not yet been investigated in the Piétrain, a breed showing a lower feed intake and a greater carcass leanness than Large White, Landrace or Duroc breeds (Labroue, F., Guéblez, R., Meunier-Salaün, M. C., et al., 1999; Mérour, I., Tribout, T., and Hermesch, S., 2010). The high lean content of the purebred Piétrain animals is mainly due to the high frequency of the halothane sensitivity allele in this breed. No comparison of RFI between the three halothane genotypes has seemingly been performed up to now.

The aim of this study was to estimate genetic parameters for RFI and other performance traits in Piétrain growing pigs and quantify the effect of the halothane genotype on those traits.

\section{Material and methods}

Animals and data recording. Data were collected on 2312 purebred Piétrain females tested between 2002 and 2009 in the three French central test stations. The purebred Piétrain animals were sourced from 15 herdbook herds participating in the French national breeding schemes. Piglets entered the station at young ages (two weeks in one station, five weeks in the two others).

Pigs from the same herd were housed in pens of around 12 animals and fed ad libitum with one single-place electronic feeder Acema 64 (Labroue, F., Guéblez, R., Sellier, P., et al., 1994). On-test weight $\left(\mathrm{BW}_{1}\right)$ and off-test weight $\left(\mathrm{BW}_{2}\right)$ were around 35 and $107 \mathrm{~kg}$, respectively. Average daily feed intake (ADFI), average daily gain (ADG), and feed conversion ratio (FCR) were computed.

Pigs were slaughtered in two commercial abattoirs. Carcasses were then chilled in a cooling room at $4^{\circ} \mathrm{C}$ for 24 hours. Dressing percentage (DP) was defined as the ratio of cold carcass weight to slaughter weight. The normalized cutting procedure was applied to right halfcarcasses.

Carcass backfat thickness (BFT: average of three measurements taken on the mid-dorsal line), and weights of shoulder, ham, loin, belly and backfat were recorded. Lean meat content (LMC) was estimated from a linear combination of ham, loin and backfat weights, expressed in percentage of the half-carcass weight (Daumas, G., 2008).

\footnotetext{
${ }^{\dagger}$ : INRA, UMR 1313 GABI, 78352 Jouy-en-Josas Cedex, France

‡ : IFIP-Institut du Porc, 35651 Le Rheu Cedex, France
} 
Halothane genotype (NN: homozygous halothane negative, Nn: heterozygous halothane negative, and nn: homozygous halothane positive) was determined using a DNA test (Fujii, J., Otsu, K., Zorzato, F., et al., 1991) or, in some cases, deduced from the genotypes of the parents.

Statistical analyses. Only batches (= contemporary groups, with 73 levels) with at least two halothane genotypes represented were kept for this study. Number of animals per pen was divided into 5 classes: < 6, 7-8, 9-10, 11-12, and > 12 animals.

The predicted daily feed intake on the test period was calculated by a multiple regression of ADFI on ADG, BFT, LMC, DP and average metabolic weight $\left(\mathbf{A M W}=\left(\mathrm{BW}_{2}^{1.6}-\mathrm{BW}_{1}{ }^{1.6}\right) /\right.$ [1.6 $\left(\mathrm{BW}_{2}-\mathrm{BW}_{1}\right)$ ]; Noblet, J., Karege, C., Dubois, S., and Van Milgen, J., 1999) with batch and pen size taken into account as fixed effects, resulting in the following definition of residual feed intake:

RFI, $g=$ ADFI, $g$ - 1.35 ADG, $g$ - 107.5 AMW, $k g-3.8$ DP, $\%$ - 3.1 BFT, $m m$ + 26 LMC, $\%$. The coefficient of determination of the model used to compute the predicted feed intake was $\mathrm{R}^{2}=0.78$.

Estimates of genetic parameters were obtained using the WOMBAT software (Meyer, K., 2006) applied to a multitrait individual animal model. The fixed effects included in the model were halothane genotype and batch for all traits and, in addition, pen size for ADG, ADFI and FCR. The model also included $\mathrm{BW}_{1}$ for growth traits, and carcass weight for carcass traits as covariates. Common environment of the litter was added as random effect for all traits (1846 levels). The pedigree file (6799 animals) contained five generations of ancestors of the recorded animals.

Pairwise contrasts between halothane genotype means were estimated using the PEST software (Groeneveld, E., and Kovac, M., 1990) applied to a single trait animal model using variance components estimated with WOMBAT.

\section{Results and discussion}

Among the 2312 Piétrain female pigs tested, 176 (7.6\%), 470 (20.3\%) and 1666 (72.1\%) were NN, Nn and nn at the halothane locus, respectively. Phenotypic means and standard deviations of the traits are shown in Table 1.

Table 1: Summary statistics for the seven traits studied $(\mathrm{N}=\mathbf{2 3 1 2})$

\begin{tabular}{lcc}
\hline \multicolumn{1}{c}{ Trait } & Mean & Standard Deviation \\
\hline RFI, $g$ & 0 & 111 \\
ADFI, $g$ & 2084 & 235 \\
ADG, $g$ & 837 & 96 \\
FCR, $\mathrm{kg}$ feed/ kg gain & 2.50 & 0.19 \\
LMC, \% & 65.4 & 2.2 \\
BFT, $\mathrm{mm}$ & 18.1 & 3.5 \\
DP, $\%$ & 82.2 & 1.3 \\
\hline
\end{tabular}

Genetic parameters are given in Table 2. Our heritability estimate for RFI $(0.40 \pm 0.06)$ was in the upper range of the literature values reviewed by Hoque, M. A. and Suzuki, K. (2009).

RFI was positively correlated, at both phenotypic and genetic levels, with ADFI and, to a greater extent, with FCR. These close relationships were also reported by Gilbert, H., 
Bidanel, J.-P., Gruand, J., et al. (2007), Caï, W., Casey, D. S., and Dekkers, J. C. M. (2008) and Sellier, P., Billon, Y., Riquet, J., et al. (2010) in Large White pigs. As expected, RFI was phenotypically independent of ADG, LMC, BFT, and DP, i.e. four of the five traits used for the prediction of feed intake. Corresponding genetic correlations with RFI were close to zero for ADG and BFT and marginally negative for LMC $(-0.16 \pm 0.12)$ and DP $(-0.14 \pm 0.12)$. The previous studies dealing with genetic correlations between RFI and body composition traits had consistently shown a trend to positive values for fatness traits (e. g. backfat thickness) and negative values for leanness traits (e. g. loin muscle area). The breeds involved in those studies differed from that of the current study, and our results could indicate that the genetic relationship between RFI and body composition is weaker in Piétrain than in Large White, Landrace or Duroc breeds.

Table 2: Estimates of heritabilities, genetic and phenotypic correlations ${ }^{a}$

\begin{tabular}{lccccccc}
\hline \multicolumn{1}{c}{ Trait } & RFI & ADFI & ADG & FCR & LMC & BFT & DP \\
\hline RFI &. $\mathbf{4 0}$ & .49 & -.06 & .85 & -.16 & .01 & -.14 \\
ADFI & .47 & .54 & .79 & .16 & -.75 & .42 & -.47 \\
ADG & .00 & .78 & .58 & -.46 & -.52 & .28 & -.51 \\
FCR & .70 & .31 & -.35 & .47 & -.25 & .13 & .06 \\
LMC & .00 & -.55 & -.43 & -.16 & .47 & -.67 & .30 \\
BFT & .00 & .30 & .26 & .05 & -.41 & .37 & -.14 \\
DP & .00 & -.08 & -.12 & .06 & .19 & .07 & .50 \\
\hline
\end{tabular}

${ }^{\alpha}$ Heritabilities on the diagonal (s.e. between 0.06 and 0.07 ), phenotypic and genetic (s.e. between 0.03 and 0.13 ) correlations below and above the diagonal, respectively.

Pairwise contrasts between the three halothane genotypes are presented in Table 3. No significant effect of halothane genotype was found for RFI. Gilbert, H., Riquet, J., Gruand, J., et al. (2010) have also found no significant difference in RFI between NN and Nn animals issued from Large White dams mated with Piétrain $\times$ Large White boars.

Table 3: Estimates of the pairwise contrasts between halothane genotype effects

\begin{tabular}{lccc}
\hline \multicolumn{1}{c}{ Trait } & NN-nn & NN-Nn & Nn-nn \\
\cline { 2 - 4 } RFI, $g$ & $4.5 \mathrm{NS}$ & $3 \mathrm{NS}$ & $1.5 \mathrm{NS}$ \\
ADFI, $g$ & $79 * * *$ & $4 \mathrm{NS}$ & $75^{* * *}$ \\
ADG, $g$ & $9 \mathrm{NS}$ & $-11 \mathrm{NS}$ & $21 * * *$ \\
FCR, $\mathrm{kg}$ feed/kg gain & $0.07 * * *$ & $0.04 *$ & $0.03 * *$ \\
LMC, $\%$ & $-2.2 * * *$ & $-0.8 * * *$ & $-1.5 * * *$ \\
BFT, $\mathrm{mm}$ & $1.4 * * *$ & $0.3 \mathrm{NS}$ & $1.1 * * *$ \\
$\mathrm{DP}, \%$ & $-1.0 * * *$ & $-0.3 *$ & $-0.7 * * *$ \\
\hline *** $\mathrm{P}<0.001 ; * * \mathrm{P}<0.01 ; * \mathrm{P}<0.05$ & &
\end{tabular}

Animals with the $\mathrm{nn}$ halothane status displayed a markedly lower ADFI than Nn and NN animals $(\mathrm{P}<0.001)$. There was no significant difference between NN and Nn animals for ADFI and ADG whereas Gilbert, H., Riquet, J., Gruand, J., et al. (2010) reported significantly higher ADFI (+ 70 g) and ADG (+20 g) in NN than in Nn animals. However, the lack of difference in ADG between NN and Nn pigs is in accordance with, e.g., Larzul, C., Le Roy, P., Guéblez, R., et al. (1997). The favourable effect of the $\mathrm{n}$ allele on FCR was previously reported in the 'NN vs. Nn' comparisons of Gilbert, H., Riquet, J., Gruand, J., et 
al. (2010) whereas Larzul, C., Le Roy, P., Guéblez, R., et al. (1997) did not find a significant influence of the halothane genotype on this trait. Note that, in our study, the genetic correlations were estimated using the halothane genotype as fixed effect, which could explain the high genetic correlation found between RFI and FCR while the effects of the three genotypes were not significant on RFI but were significant on FCR. The welldocumented advantage of nn over NN animals in dressing percentage, backfat thickness and carcass lean meat content is confirmed by the current study. In addition, our results suggest that Nn pigs are closer to NN than to nn pigs in this respect. The latter feature was previously reported by Larzul, C., Le Roy, P., Guéblez, R., et al. (1997) for fat thickness.

\section{Conclusion}

Residual feed intake of the growing animals appears to be moderately to highly heritable and unaffected by the halothane status in the Piétrain breed. The nn pigs as compared to Nn or NN pigs eat less feed, have a slower growth, and give a heavier carcass with more lean meat content and less subcutaneous fat. There is a strongly positive association, at the genetic level, between residual feed intake and feed conversion ratio within the Piétrain breed.

\section{References}

Caï, W., Casey, D. S., and Dekkers, J. C. M. (2008). J. Anim. Sci., 86:287-298.

Daumas, G. (2008). Journées Rech. Porcine, 40:61-68.

Fujii, J., Otsu, K., Zorzato, F., et al. (1991). Science, 253:448-451.

Gilbert, H., Bidanel, J.-P., Gruand, J., et al. (2007). J. Anim. Sci., 85:3182-3188.

Gilbert, H., Riquet, J., Gruand, J., et al. (2010). Animal, in press.

Groeneveld, E., and Kovac, M. (1990). J. Dairy Sci., 73:513-531.

Hoque, M. A., Suzuki, K. (2009). Asian-Australasian J. Anim. Sci. 17 Feb, 2010. http://findarticles.com/p/articles/mi_6917/is_5_22/ai_n31878034.

Kennedy, B. W., Van der Werf, J. H., and Meuwissen, T.-H. E. (1993). J. Anim. Sci., 71:3239-3250.

Koch, R. M., Swiger, L. A., Chambers, D., and Gregory, K. E. (1963). J. Anim. Sci., 22:486-494.

Labroue, F., Guéblez, R., Sellier, P., and Meunier-Salaün, M. C. (1994). Livest. Prod. Sci., 40:303-312.

Labroue, F., Guéblez, R., Meunier-Salaün, M. C., and Sellier P. (1999). Ann. Zootech., 48:247-261.

Larzul, C., Le Roy, P., Guéblez, R., et al. (1997). J. Anim. Breed. Genet., 114:309-320.

Mérour, I., Tribout, T., and Hermesch, S. (2010). Journées Rech. Porcine, 42:161-166.

Meyer, K. (2006). In Proc $8^{\text {th }}$ WCGALP, session 27c, communication 27-14.

Noblet, J., Karege, C., Dubois, S., and Van Milgen, J. (1999). J. Anim. Sci., 77:12081216.

Sellier, P., Billon, Y., Riquet, J., et al. (2010). Journées Rech. Porcine, 42:167-172. 